\title{
Multi-criteria analysis on mapping of areas for mechanized forest harvesting
}

\author{
Análise multicritério no mapeamento de áreas para a colheita \\ florestal mecanizada
}

\author{
Stanley Schettino', Luciano José Minette ${ }^{2}$, Fabricio Silva ${ }^{2}$, Isabela Dias Reboleto ${ }^{2}$, \\ Ítalo Lima Nunes ${ }^{2}$ and Carolina Freitas Schettino ${ }^{1}$
}

\begin{abstract}
This study aimed to test the method of multi-criteria analysis, in the platform of the Geographic Information System (GIS), to perform mapping in levels of suitability for the mechanized harvesting of eucalyptus forests. The study was carried out using eucalyptus stands for cellulose production in the State of Minas Gerais, Brazil. The main factors that influenced the mechanized forest harvesting were determined, as well as the technical and environmental constraints. The quantitative factors (declivity, productivity of the plots, volume per tree, age of planting and number of trees per hectare) were standardized using fuzzy logic. To combine the factors, weights for each of them were established through the AHP (Analytic Hierarchy Process) technique. From these weights, Weighted Linear Combination (WLC) was performed and a map of suitability for mechanized forest harvesting was generated. The mapping process allowed to classify the forest area into five suitability classes: very low $(0.2 \%)$; low $(3.3 \%)$; average $(15.2 \%)$; high $(53.0 \%)$ and very high $(28.3 \%)$. The declivity factor was the criterion that most influenced the spatialization in the areas of suitability for forest harvesting with the harvester. The method of multi-criteria analysis has been shown to be an efficient tool to create maps of suitability for the operation with the harvester and to support wood harvest planning by identifying areas that tend to have lower or higher productivity.
\end{abstract}

Keywords: Forest harvesting planning; Fuzzy logic; Decision support system; Analytic Hierarchy Process.

\section{RESUMO}

Este estudo teve como objetivo testar o método de análise multicritério, na plataforma do Sistema de Informação Geográfica (SIG), para realizar mapeamento em níveis de adequabilidade para o corte mecanizado de florestas de eucalipto. O estudo foi realizado utilizando povoamentos de eucalipto para produção de celulose no Estado de Minas Gerais, Brasil. Os principais fatores que influenciavam o corte florestal mecanizado foram determinados, bem como as restrições técnicas e ambientais. Os fatores quantitativos (declividade, produtividade dos talhões, volume por árvore, idade do plantio e número de árvores por hectare) foram padronizados com a utilização da lógica fuzzy. Para combinar os fatores, foram estabelecidos pesos para cada um deles por meio da técnica AHP (Analytic Hierarchy Process). A partir destes pesos, foi realizada a combinação linear ponderada WLC (Weighted Linear Combination) e gerado um mapa de adequabilidade para o corte florestal mecanizado. O processo de mapeamento realizado permitiu classificar a área florestal em cinco classes adequabilidade: muito baixa ( $0,2 \%)$; baixa (3,3\%); média $(15,2 \%)$; alta $(53,0 \%)$ e muito alta $(28,3 \%)$. O fator declividade foi o critério que mais influenciou na espacialização nas áreas de adequabilidade para o corte florestal com o harvester. O método de análise multicritério demonstrou ser uma ferramenta eficiente para criar mapas de adequabilidade para a operação com o harvester e apoiar o planejamento da colheita da madeira por meio da identificação de áreas que tendem a ter uma menor ou maior produtividade.

Keywords: Planejamento da colheita florestal; Lógica Fuzzy; Sistemas de suporte a decisão; Processo de análise hierárquica.

\section{INTRODUCTION}

In a forest enterprise, wood harvesting can be considered one of the most important steps for the success of a forest company, since the higher costs that compose the final value of the wood are in this stage. According to Machado and Lopes (2000), the forest harvesting and transportation can represent up to $50 \%$ of the wood final cost.

1. Universidade Federal de Minas Gerais - UFMG. Montes Claros, MG, Brazil.

2. Universidade Federal de Viçosa - UFV. Viçosa, MG. Brazil.

* Corresponding author: schettino@ufmg.br

Sci. For., Piracicaba, v. 47, n. 124, p. 766-775, dez. 2019

DOI: doi.org/10.18671/scifor.v47n124.18 
In harvesting systems, the productivity of the cut is influenced by several factors of the physical environment and aspects of the stand. In order to achieve the technical, economical and environmental viability of the harvesting modules, it is essential to use some tools that help in the process of the activity planning.

For a detailed planning of the activities, it is important to know the effects of the variables that affect the mechanized harvesting. According to Simões et al. (2010), studies on variables that influence machine productivity are essential to minimize costs and optimize the forest harvesting process.

The operation with the harvester is influenced by several environmental and operational variables that may even make machine use unfeasible (LEITE et al., 2013). In their study, Malinovski et al. (2006) identified 27 variables that influence harvester productivity, including, among others: terrain declivity, soil type, individual volume, volume per hectare and planting spacing.

Several specific studies were carried out in forest harvesting with the objective of determining and quantifying the variables of influence on harvester productivity. The study developed by Jiroušek et al. (2007) considers the volume per tree being the factor that most interferes on harvester productivity. According to Leite et al. (2013), slope is the variable that has the greatest effect on harvester productivity above an inclination of $15^{\circ}$.

Bramucci and Seixas (2002) cite that, for eucalyptus plantations, the age of cut has a relation with the productivity of the harvesters, being quite evident the increase of productivity of this machine in stands between six and ten years of age. Also, when using the number of trees as a technical variable in harvester productivity, the authors determined that the ideal range for higher productivity is between 800 and 1200 trees per hectare, at harvest time, since there is a direct relationship between the density of the forest and the individual volume of the trees.

Given the enormous amount of technical variables that affect harvester performance, it is important to apply scientifically based methodologies to assist the forest harvesting planning process. The use of the Geographic Information System (GIS) along with multi-criteria analysis methods can provide numerous advantages for solving real world planning and management problems (ZAMBON et al., 2005). The multi-criteria analysis in the GIS environment has been a widely used technique to define more suitable areas for installation of enterprises, environmental risk analysis, environmental sensitivity analysis and land use planning (MALCZEWSKI, 2004; SARTORI et al., 2014).

Based on the multi-criteria analysis to support decision-making in the GIS environment, several factors and constraints that influence forest harvesting can be associated to establish the most suitable areas for the mechanized activity. In the multi-criteria analysis, the AHP (Analytic Hierarchy Process) method has been the most used to solve decision-making problems (DENG, 1999).

In this way, the objective of this study was to test the multi-criteria analysis method, in the platform of the Geographic Information System, to perform mapping in levels of suitability for the mechanized harvesting of eucalyptus stands.

\section{MATERIAL AND METHODS}

\section{Characterization of the study area}

This study was developed in areas of a forest company located in the municipalities of Catas Altas da Noruega and Alvinópolis, Minas Gerais State, Brazil, located between the parallels $20^{\circ} 01^{\prime} 28^{\prime \prime}$ and $20^{\circ} 10^{\prime} 12^{\prime \prime}$ latitude south of the Equator line and between the meridians $43^{\circ} 17^{\prime \prime} 11^{\prime \prime}$ and $43^{\circ} 23^{\prime \prime} 40^{\prime \prime}$ longitude west of Greewinch. The relief ranges from soft wavy to undulated. It presents a humid moderate subtropical climate, Cwb type, with abundant precipitations in the summer (averages of 1,450 to $1,800 \mathrm{~mm}$ ) and cold temperatures, with an annual average varying between 17 and $18.5^{\circ} \mathrm{C}$.

The study area had 2,545.17 hectares of effective planting area. In this area, the forests are all grown with eucalyptus in stands of hybrid clones of different yields (from 105 to $457 \mathrm{~m}^{3} / \mathrm{ha}$, according to the genetic material and the site classes), in a first rotation regime with 7 years of average harvesting age, $3 \times 2.5 \mathrm{~m}$ spacing, with average density of 1,213 trees/ha at harvest time. The following soil types were found in the study area: lateritic soils (yellow Latosol, red Latosol, red-yellow Latosol and purple Latosol) and non-lateritic soils (red-yellow Argisol, Cambisol and Neosol). 
Schettino et al. - Multi-criteria analysis on mapping of areas for mechanized

forest harvesting

For the purposes of this study, it was considered the cut-to-length harvesting system, in which, according to Malinovski et al. (2014), the tree is felled and all activities complementary to the cut (delimbing, top cutting and tracing) are carried out at the site of felling.

\section{Cartographic basis and data processing}

The database used in this study was formed by vectoring the contour lines and points quoted from the Catas Altas sheet (SF.23-XBI-1; scale: 1:50,000) from the systematic survey of the Brazilian Institute of Geography and Statistics (IBGE). Through the interpolation of the altimetry values and vector themes previously described, the Digital Elevation Model (DEM) and the slope of the terrain (in degrees) were generated, with a cell size of 10 meters.

Other information plans used in this work were made available in the vector format by the forest company, such as: permanent preservation areas; soil classes; forest roads; native forests; hydrography; legal reserve; perimeter of projects and registration data of forest inventory.

The IDRISI Andes software (EASTMAN, 2006) and ArcGIS 10.2 (ESRI, 2013) were used for data processing and thematic map production.

\section{Selection of criteria and constraints}

The surfaces that represented the main influencing factors and constraints of the forest harvesting formed or derived based on different approaches, with the main factors being converted to the raster format compatible with IDRISI, adopting the same DEM cell size.

The factors used in this study were: slope; volume per hectare; volume per tree; planting age; number of trees per hectare and soil class. The criteria used as areas of environmental or technical constraint were: permanent preservation areas; legal reserves; roads; native forests; declivities above $36^{\circ}$ and third party areas.

\section{Standardization of factors}

The conversion of the factors to a single scale of values was necessary to proceed with the combination of the variables, in order to form a final map of suitability. For that, fuzzy logic was used, which is a tool capable of capturing vague information, usually described in natural language and converting them to a numerical format, which is easy to manipulate (CANEPPELE; SERAPHIM, 2013). Based on these variables, analyzes were performed from functions of the fuzzy set to standardize the factors in a byte-level suitability, ranging from 0 to 255 levels. The functions for each variable and their respective control points are described below.

In the case of the factor slope, the monotonically decreasing fuzzy linear function was used for the continuous standardization of suitability, that is, the flatter the terrain, the better the conditions. The suitability value decreases with increasing slope, that is, larger slopes become less adequate. The $0^{\circ}$ value was considered as the first control point of the function and the value $36^{\circ}$ was considered as the second control point, and with slopes above $36^{\circ}$ the productivity of the machine analyzed become unfeasible. The declivity of the terrain was calculated in degrees from the Elevation Digital Model - EDM of the study area.

In relation to the factor productivity of the area, the monotonically increasing fuzzy sigmoidal function was used for the continuous standardization of adequacy, that is, higher the productivity, better the results. The suitability value decreases according to the reduction of productivity, that is, less productive areas become less adequate. The value $105 \mathrm{~m}^{3} /$ ha was considered as the first control point of the function, that is, areas with lower productivity. As a second control point, the value of $457 \mathrm{~m}^{3} /$ ha was considered, being the maximum value of productivity found. These values are based on the lowest and highest productivity found in the forests of the study area.

For the variable volume per tree, the monotonically increasing fuzzy linear function was used for the continuous standardization of adequacy, that is, higher the volume per tree, better the conditions for forest harvesting. The suitability value increases with increasing volume per tree, that is, they become more adequate. The value of $0.10 \mathrm{~m}^{3} /$ tree was considered as the first control point of the function and the value of $0.47 \mathrm{~m}^{3} /$ tree was considered as the second control point, these being the extreme values found in the studied area. These values are based on the lowest and the highest mean individual volume per tree found in the forests of the study area at harvest time.

In relation to the variable age of planting, the monotonically increasing fuzzy linear function was used for the continuous standardization of adequacy, that is, longer the age of planting, better 
the conditions for forest harvesting. The suitability value increases with increasing age, that is, they become more adequate. The value of 3 years was considered as the first control point of the function and the value of 10 years was considered as the second control point, with the plantings with less than 3 years being unfeasible for harvesting.

Before the age of three years no woody material is generated and therefore the withdrawal of the stands is not considered a harvest. Also, in order to reconcile operational objectives (small discontinuous areas, e.g.) and production regulation, it is possible that in some cases the harvest will be postponed until the tenth year.

On the other hand, for the factor number of trees per hectare, the symmetric sigmoidal fuzzy function was used for standardization of adequacy, that is, the function follows certain symmetry. The suitability value increases with the increase in the number of trees per hectare, then the suitability remains maximum up to a certain value and then decreases. These control points were, respectively, $0 ; 1,000 ; 1,500$ and 2,000 trees/ha.

The suitability of soil classes was defined according to the mechanization support capacity. Regions with soil type more favorable for forest harvesting mechanization were considered with higher suitability values and less favorable regions were considered with lower suitability values. Lateritic soils have a more favorable behavior for mechanization since they offer greater stability and have deeper layers and, for this reason, were considered with higher suitability values. On the other hand, non-lateritic soils were considered unfavorable.

\section{Constraints}

The constraints are considered from the criteria that in this study represent limitations for mechanized forest harvesting. They were: permanent preservation areas; legal reserve; roads; native forest; slopes above $36^{\circ}$; and third-party areas. The constraints were expressed in the form of Boolean (logic) maps, with the inapt areas being coded with value zero (0) and those apt areas with value one (1). The final constraint map was obtained by the overlapping of the Boolean images.

\section{Factor weighting}

The definition of the factor weights was performed by the AHP (Analytic Hierarchy Process) technique that allows the comparison of factor pairs in terms of their relative importance. The importance values for the considered factors were obtained from the matrix of comparison between the criteria. The comparisons refer to the relative importance between each pair of factors involved in determining suitability for a given scenario.

The factor weights were calculated from the processing of special algorithms present in the GIS software's that simultaneously calculate the Consistency Ratio (CR). The factor weights were established according to the following order of importance: slope, volume per hectare, volume per tree, planting age, tree per hectare and soil class.

\section{Combination of criteria}

Once the criteria were standardized in the range of values from 0 to 255 , the factors were combined according to the decision rule and, for each decision variable, the value 0 was assigned to the first control point and 255 to the last control point. The intermediate points received the equivalent values after the application of the corresponding fuzzy function.

In this study, the criteria aggregation procedure was performed by the Weight Linear Combination (WLC). When using WLC, the factors are combined (Figure 1), applying a weight to each of them, followed by an addition of the results to produce a suitability synthesis map, presented at Equation 1 (GHISELLI RICCI; MESIAR, 2011).

$$
s=\sum W_{i} \cdot X_{i}
$$

On which: $\mathrm{S}=$ Adequacy; $\mathrm{W}_{\mathrm{i}}=$ Weight of factor $\mathrm{i}$; and $\mathrm{X}_{\mathrm{i}}=$ record of the criterion for factor $\mathrm{i}$.

For Boolean constraint, it is necessary to multiply the calculated adequacy of the factors by the product of the constraints, according Equation 2 proposed by Eastman et al. (1995):

$$
s=\sum W_{i} \cdot X_{i} * \prod c_{i}
$$

On which: $\mathrm{S}=$ Adequacy; $\mathrm{X}_{\mathrm{i}}=$ Record of the criterion for factor $\mathrm{i} ; \mathrm{c}_{\mathrm{j}}=$ Record of the criterion for the constraint $\mathrm{j}$; and $\Pi=$ Product. 


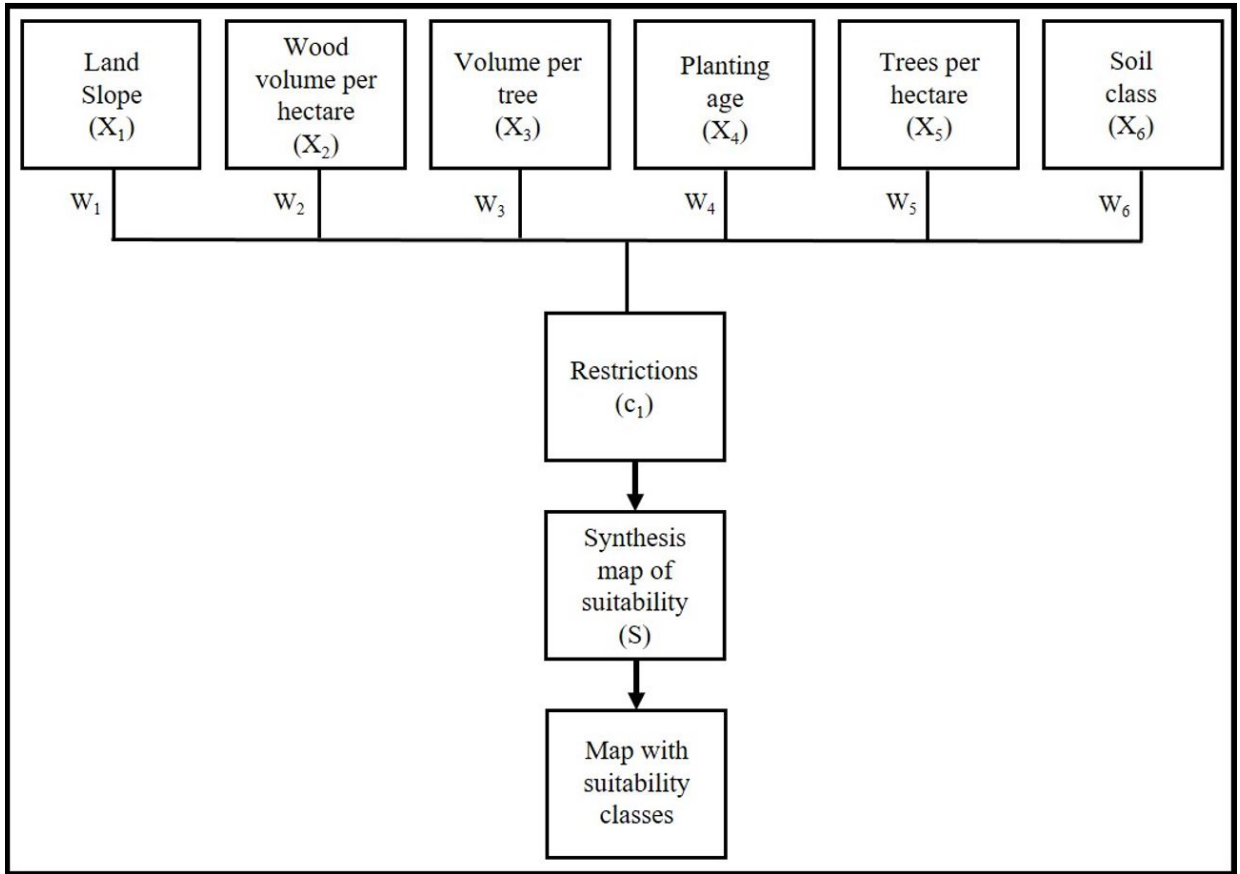

Figure 1 - Representation of the proposed Weighted Linear Combination metho.

Figura 1 - Representação do método da Combinação Linear Ponderada proposto.

\section{RESULTS AND DISCUSSION}

From the factors in hierarchical order and with the use of the Idrisi32 Weight module, the calculation of the junction of all standardized images created from each of the factors was performed. Among the six factors studied, five were standardized using fuzzy logic set functions and only the soil types were categorically rescaled according to project preferences.

Then, from the Analytic Hierarchy Process method, a peer-to-peer comparison matrix between the factors was created, according to its relative importance. Table 1 shows the weights and priority values of the factors represented in the paired comparison matrix used in the AHP method. The variables that interfere in the operational performance of the mechanized forest harvesting were established according to the order in the matrix with the importance of each factor for the aptitude of the area. This weighting established in the comparison matrix had a direct influence on the spatialization of areas of suitability for mechanized forest harvesting.

Table 1 - Weights and priority values of the factors represented in the paired comparison matrix used in the AHP method

Tabela1 - Pesos e valores de prioridade dos fatores representados na matriz de comparação pareada utilizados no método AHP

\begin{tabular}{lccccccc}
\hline \multicolumn{1}{c}{ Factors $\left(\mathbf{X}_{\mathbf{i}}\right)^{*}$} & Slope & $\begin{array}{c}\text { Volume per } \\
\text { hectare }\end{array}$ & $\begin{array}{c}\text { Volume } \\
\text { per tree }\end{array}$ & $\begin{array}{c}\text { Age of } \\
\text { planting }\end{array}$ & $\begin{array}{c}\text { Tree per } \\
\text { hectare }\end{array}$ & Soil Class & Weights $\left(\mathbf{W}_{\mathbf{i}}\right)^{*}$ \\
\hline Slope & 1 & & & & & & 0.4653 \\
Volume per hectare & $1 / 4$ & 1 & & & & & 0.1745 \\
Volume per tree & $1 / 4$ & $1 / 2$ & 1 & & & & 0.1638 \\
Age of planting & $1 / 5$ & $1 / 2$ & $1 / 2$ & 1 & & & 0.1017 \\
Tree per hectare & $1 / 5$ & $1 / 3$ & $1 / 4$ & $1 / 2$ & 1 & & 0.0671 \\
Soil Class & $1 / 9$ & $1 / 6$ & $1 / 6$ & $1 / 5$ & $1 / 4$ & 1 & 0.0276 \\
\hline
\end{tabular}

* $\mathrm{X}_{\mathrm{i}}=$ Record of the criterion for factor $\mathrm{i} ; \mathrm{W}_{\mathrm{i}}=$ Weight of factor $\mathrm{i}$.

The consistency ratio obtained for the matrix was 0.04, indicating that the values were generated randomly and did not require a reorganization of the comparison matrix.

The maps of the stand factors (A-D) are presented in Figure 2. Figure 3 shows the maps of the factors related to the physical environment (A and B) and the constraint factor (C). Factor maps have standard values in the range of values from 0 to 255, except for the constraint map that has Boolean values. 

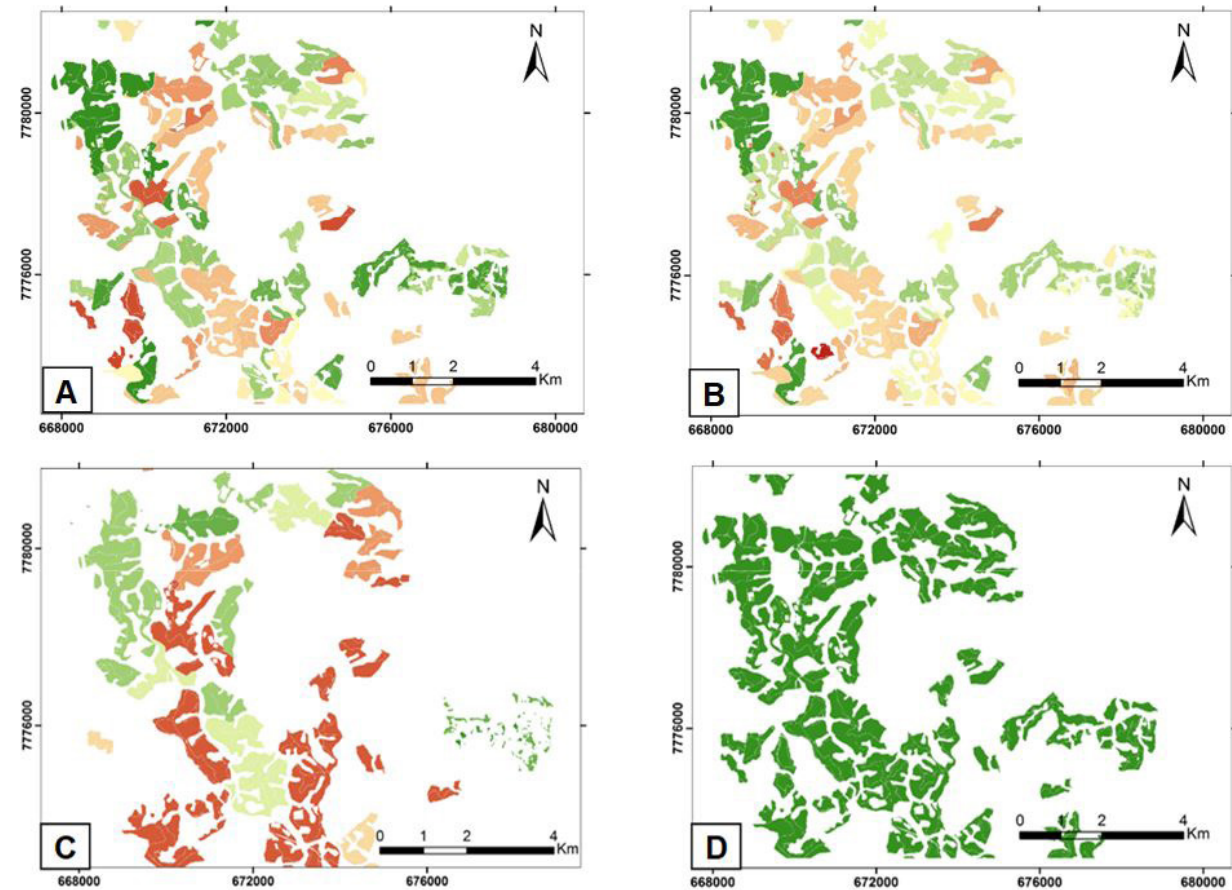

Legend

Suitability values:

$255-$ High suitability
200
150
100
50
$0-$ Low suitability

Universal Transverse "23s, Datum “Córrego Alegre".

Figure 2 - Factors standardized in the scale of values from 0 to 255, being: A) volumetric productivity per hectare; B) individual volume per tree; C) age; D) trees per hectare.

Figura 2 - Fatores padronizados na escala de valores de 0 a 255, sendo: A) produtividade volumétrica por hectare; B) volume individual por árvore; C) idade; D) árvores por hectare.
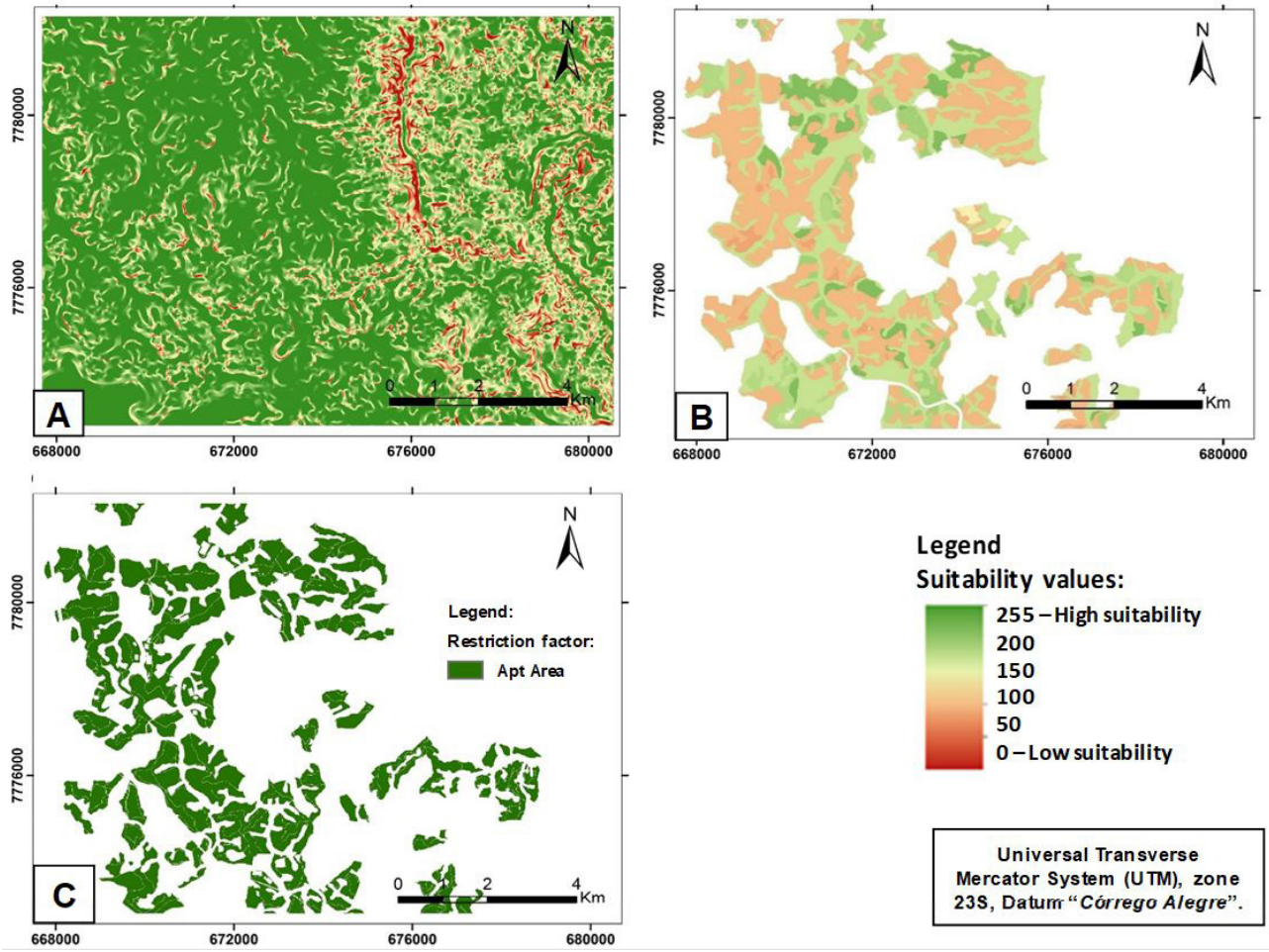

Figure 3 - Factors standardized in the scale of values from 0 to 255 and constraint, being: A) terrain slope; B) soil types; C) constraint.

Figura 3 - Fatores padronizados na escala de valores de 0 a 255 e restrição, sendo: A) declividade do terreno; B) xclasse de solo; C) restrição. 
Schettino et al. - Multi-criteria analysis on mapping of areas for mechanized

forest harvesting

In Figure 2, the map of the factor volumetric productivity per hectare (Figure 2A) indicates that the regions with the highest adequacy correspond to those with the highest productivity per hectare $\left(\mathrm{m}^{3} / \mathrm{ha}\right)$. Similarly, the map of the factor volume per tree (Figure $2 \mathrm{~B}$ ) shows that the areas of greatest suitability represent the areas with the highest tree individual average volume $\left(\mathrm{m}^{3} / \mathrm{tree}\right)$. The map of the factor age (Figure $2 \mathrm{C}$ ) indicates that the areas of greatest suitability correspond to the areas with the highest planting age.

In terms of forest productivity, forest harvesting machines positively have a large response to the volume of the stands, and the increased productivity of these machines is directly proportional to the increase in the volume of the stands (SCHETTINO et al., 2015). According to Oliveira Junior et al. (2009), this is verified due to the tree individual average volume, which tends to be larger the greater the volume of the forests is, considering the same spacing and number of trees per hectare, as it is the case of this study.

In the map of the factor trees per hectare (Figure 2D) there is no apparent variation in the adequacy levels, being an indication that the number of trees per hectare at the study area is within the ideal or more adequate range, according to the control points established in the factor standardization, that is, there are no significant variations in the number of trees in the stands of the study area.

In the scale of importance as for the suitability for the mechanized forest harvesting, we have the volume per tree in the sequence. In fact, Martins et al. (2009) concluded that the mean volume per tree was the variable that best explained the effective operational capacity of the harvester. Then, larger spacing result in greater individual volume per tree, which consequently influence the best performance of this machine.

Although the forest density, expressed in number of trees per hectare, is a factor that has a close and important relation with harvester productivity (BRAMUCCI; SEIXAS, 2002), in this study it was one of the factors that least affected the development of the suitability synthesis map. This fact is due to the intrinsic characteristics of the evaluated forests, which had little variability in relation to forest density although they presented great variations of volume per hectare, and then it was not possible to evaluate the real effect of this factor in the elaboration of the map of suitability for the mechanized harvesting.

In Figure 3, the map of the factor slope (Figure 3A) indicates that areas with greater suitability are located in places with low slope. In areas apt to mechanized harvesting, 740.10 ha $(29.1 \%)$ are lowland (slope varying from $0^{\circ}$ to $\left.5^{\circ}\right), 1,717.98$ ha $(67.5 \%)$ are slope (ranging from $5^{\circ}$ to $36^{\circ}$ ) and the remaining 87.06 ha $(3.4 \%)$ are above $36^{\circ}$ of slope.

The factor declivity was the criterion that most influenced the spatialization of the suitability of the areas for the forest harvesting with harvester, followed by the factors forest productivity and volume per tree. On the other hand, and considering the data of this study, the criteria of number of trees per hectare and soil class were the ones that less affected in the elaboration of the suitability synthesis map, should not be disregarded in the evaluation of other areas. The consistency ratio (0.04) obtained in the calculation of the factor comparison matrix was within the tolerable range. According to Saaty (1990), consistency ratio values lower than 0.1 do not need to be re-evaluated.

According to Akay et al. (2004), the slope of the terrain is one of the most important operational variables to consider in forest mechanization. According to Simões and Fenner (2010), topography directly affects the performance of machines in forest operations. In relation to slope, it can be said that the higher the slope, the greater the limitations for the machine displacement in the terrain and, consequently, lower the productivity (MALINOVSKI et al., 2006). Stampfer and Loschek (1999), studying the influence of tree volume and terrain slope on the productivity of a harvester of mats, showed that productivity decreases with increasing terrain slope, which is why terrain slope was the most important factor in determining the suitability for mechanized harvesting.

The map of the factor soil class (Figure 3B) indicates that the values of greater suitability are present in the lateritic soils. The constraint map (Figure 3C) has Boolean values with the representation of the suitable areas (in green), with values equal to 1 (one) and inapt areas with values equal to 0 (zero). Inapt areas correspond to the areas of the native forest, permanent preservation areas, legal reserve, roads and slope higher than $36^{\circ}$.

Figure 4 presents the final maps of suitability for mechanized harvesting, generated by the weighted linear combination of factors. The suitability surface map for mechanized forest harvesting (Figure 4A) shows values equal to 0 (zero) corresponding to inapt areas, values higher than 0 (zero) are locations 


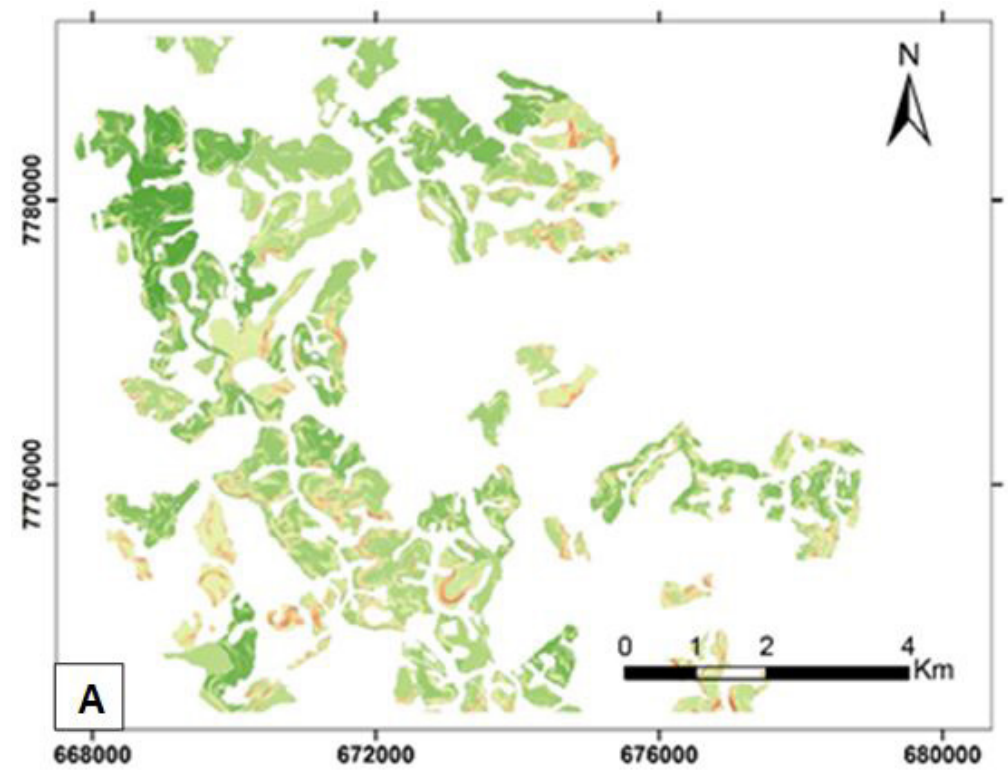

Legend

Suitability values:

255 - High suitability

200

150

100

50

0 -Low suitability

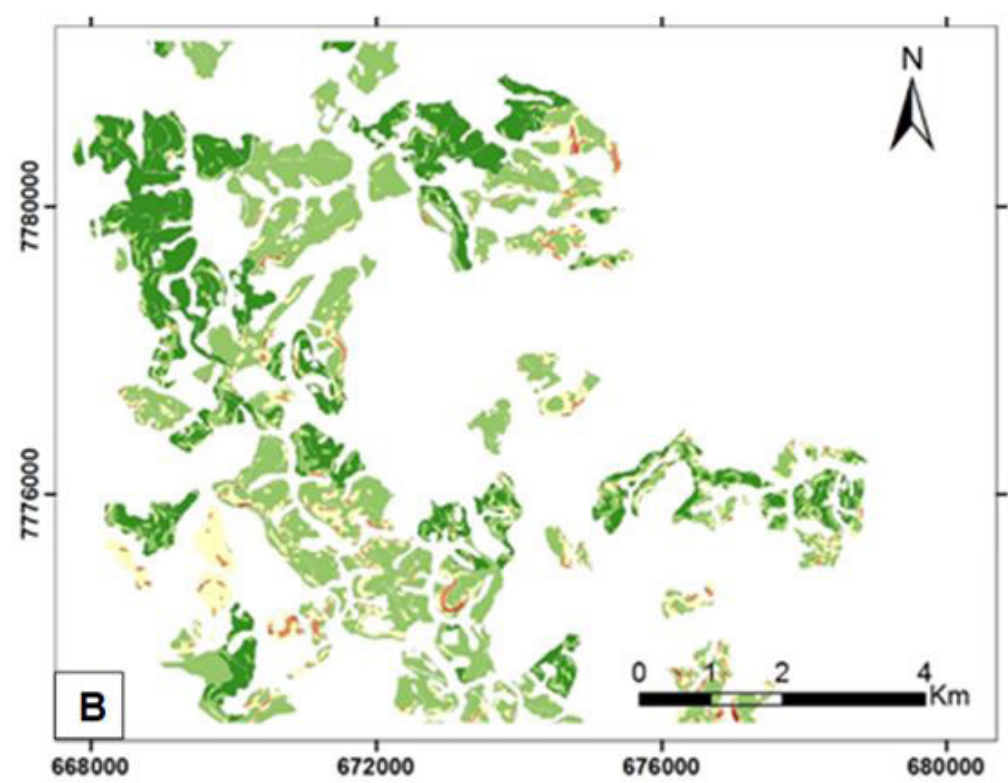

Legend

Adequacy Classes:

Very Low $(0.2 \%)$

Low $(3.3 \%)$

Medium (15.2\%)

High (53.0\%)

Very High (28.3\%)

Universal Transverse

Mercator System (UTM), zone

23S, Datum "Córrego Alegre".

Figure 4 - Maps of suitability for the mechanized forest harvesting, being: A) final map of synthesis; B) map with classes of suitability.

Figura 4 - Mapas da adequabilidade para o corte florestal mecanizado, sendo: A) mapa final de síntese; B) mapa com classes de adequabilidade.

with suitability, and the closer to 255 the higher is the level of suitability is. Considering the areas suitable for mechanized forest harvesting, the areas in each class of suitability (Figure 4B) were: very low class was 5.83 ha (0.2\%); low class was 83.29 ha (3.3\%); middle class was 387.24 (15.2\%); high class was $1,348.52$ ha (53.0\%); very high class was 720.26 ha $(28.3 \%)$.

In the planning of forest harvesting with harvester, decision-making should seek an option that presents the best performance, the best evaluation, or the best agreement between the expectations of the planner, considering the relationship between the elements. From this perspective, the decision can be defined as a process of analysis and choice among several available alternatives of the course of action that the planner should follow. Multi-criteria methods add significant value in decision-making, since they do not only allow the approach of problems considered complex and therefore not treatable by the usual intuitive-empirical procedures, but also give the decision-making process a clarity and consequently transparency not available when these procedures or other methods of a monocriteria nature are used (LAUKKANEN et al., 2005; STORE; KANGAS, 2001).

Regarding the method of multi-criteria analysis, it is observed that there are different methods to standardize the criteria in the GIS. However, it is important to note that different standardization methods can lead to different results in the final map of adequacy (GENELETTI, 2007). The map of 
Schettino et al. - Multi-criteria analysis on mapping of areas for mechanized

forest harvesting

areas with suitability with the five classes allowed a better understanding and characterization of the scenario implemented in the GIS environment. In the map of the suitability classes, it was observed that there was a higher concentration of the upper class areas and very high suitability.

Malczewski (2004) states that the analysis of land use aptitude through GIS has been applied in a variety of situations that include ecological approaches for various purposes, with activity planning being one of them. The integration between the methods of multi-criteria analysis and the GIS was an advance in the methodology of map over positioning for the determination of land use suitability, being understood as a process that combines and transforms spatial data into a response for decision-making (EASTMAN, 2006).

The multi-criteria analysis has been used in several studies related to environmental planning, such as definition of the most favorable areas for installation of companies, environmental risk analysis, environmental sensitivity analysis and planning of land use (COLLINS et al., 2001; EASTMAN, 2003; JANG; EASTMAN, 2000; MALCZEWSKI, 2004).

\section{CONCLUSIONS}

The method of multi-criteria analysis was efficient in the creation of maps of suitability for the operation with the harvester, fundamental in the process of decision-making in the elaboration of the planning of the eucalyptus forest harvesting.

The multi-criteria analysis, integrated to the fuzzy logic, presented levels of suitability assumed by the functions attributed close to reality, making feasible its use as a planning tool.

\section{REFERENCES}

AKAY, A. E.; ERDA, O.; SESSIONS, J. Determining productivity of mechanized harvesting machines. Journal of Applied Sciences, Dubai, v. 4, n. 1, p. 100-105, 2004.

BRAMUCCI, M.; SEIXAS, F. Determinação e quantificação de fatores de influência sobre a produtividade de "Harvesters" na colheita florestal. Scientia Forestalis, Piracicaba, n. 62, p. 62-74, 2002.

CANEPPELE, F.L.; SERAPHIM, O.J. Análise da eficiência energética em indústrias madeireiras através da lógica fuzzy. Energia Agricola, Botucatu, v. 28, n. 2, p. 95-102, 2013.

COLLINS, M. G., STEINER, F. R., RUSHMAN, M. J. Land-use suitability analysis in the United States: historical development and promising technological achievements. Environment Management, Heidelberg, v. 28, n. 5, p. 611-62, 2001.

DENG, H. Multicriteria analysis with fuzzy pairwise comparison. International Journal of Approximate Reasoning, Philadelphia, v. 21, p. 215-231, 1999.

EASTMAN, J.R., IDRISI Andes - Versão 16.03. Worcester: Clark University, 2006. (Software).

EASTMAN, J.R. Idrisi Kilimanjaro: Guide to GIS and Image Processing. Worcester: Clark University, 2003. 328 p.

EASTMAN, J. R.; JIN, W.; KYEM, P. A. K.; TOLEDANO, J. Raster procedures for multi-criteria/multi-objective decisions. Photogrammetric Engineering and Remote Sensing, Bethesda, v. 61, p. 539-547, 1995.

ESRI, ArcGIS Desktop - Versão 10.2. Redlands, CA: Environmental Systems Research Institute, 2013. (Software).

GENELETTI, D. An approach based on spatial multicriteria analysis to map the nature conservation value of agricultural land. Journal of Environmental Management, London, v. 83, p. 228-235, 2007.

GHISELLI RICCI, R.; MESIAR, R. Multi-attribute aggregation operators. Fuzzy Sets and Systems, London, v. 181, n. 1, p. 1-13. 2011.

JANG, H.; EASTMAN, J. R. Application of fuzzy measures in multi-criteria evaluation in GIS. International Journal of Geographical Information Science, London, v. 14, n. 2, p.173-184. 2000.

JIROUŠEK, R.; KLVAČ, R; SKOUPÝ, A. Productivity and costs of the mechanized cut-to-length wood harvesting system in clear-felling operations. Journal of Forest Science, Prague, v. 53, n. 10, p. 476-482, 2007. 
LAUKKANEN, S., PALANDER, T., KANGAS, J. \& KANGAS, A. 2005. Evaluation of the multicriteria approval method for timber-harvesting group decision support. Silva Fennica, Helsinki, v. 39, p. 249-264, 2005.

LEITE, E. S.; FERNANDES, H. C.; MINETTE, L. J.; LEITE, H. G.; GUEDES, I. L. Modelagem técnica e de custos do Harvester no corte de madeira de eucalipto no sistema de toras curtas. Scientia Forestalis, Piracicaba, v. 41, n. 98, p. 205-215, 2013.

MACHADO, C.C.; LOPES, E.S. Análise da influência do comprimento de toras de eucalipto na produtividade e custo da colheita e transporte florestal. Cerne, Lavras, v. 6, n. 2, p. 124-129, 2000.

MALCZEWSKI, J. GIS-based land-use suitability analysis: a critical overview. Progress in Planning, New York, n. 62, p. $3-65,2004$

MALINOVSKI, J. R.; CAMARGO, C. M. S.; MALINOVSKI, R. A.; MALINOVSKI, R. A.; CASTRO, G. P. Sistemas. In: MACHADO, C.C. (Ed.). Colheita Florestal. 3 ed. Viçosa: Ed. UFV, 2014. p. 178-205.

MALINOVSKI, R. A.; MALINOVSKI, R. A.; MALINOVSKI, J. R.; YAMAJI, F. M. Análise das variáveis de influência na produtividade das máquinas de colheita de madeira em função das características físicas do terreno, do povoamento e do planejamento operacional florestal. Floresta, Curitiba, v. 36, n. 2, p. 169-182, 2006.

MARTINS, R. J.; SEIXAS, F.; STAPE, J. L. Avaliação técnica e econômica de um harvester trabalhando em diferentes condições de espaçamento e arranjo de plantio em povoamento de eucalipto. Scientia Florestais, Piracicaba, v. 37, n. 83, p. 253-263, 2009.

OLIVEIRA JUNIOR, E. D.; SEIXAS, F. BATISTA, J. L. F. Produtividade de feller-buncher em povoamento de eucalipto em relevo acidentado. Floresta, Curitiba, v. 39, n. 4, p. 905-912, 2009.

SAATY, T. L. How to make a decision: the analytic hierarchy process. European Journal of Operational Research, London, v. 48, p. 9-26, 1990.

SARTORI, A. A. C.; POLONIO, V. D.; ZIMBACK, C. R. L. Adequação territorial com abordagem multicriterial pela análise da combinação linear ponderada. Revista Geociências, São Paulo, v. 33, n. 2, p.192-201, 2014.

SCHETTINO, S.; MINETTE, L.J.; SOUZA, A.P. Correlação entre volumetria de florestas de eucalipto e produtividade e custos de máquinas de colheita de madeira. Revista Árvore, Viçosa, v. 39, n. 5, p. 935-942, 2015.

SIMÕES, D.; FENNER, P. T. Influência do relevo na produtividade e custos do harvester. Scientia Forestalis, Piracicaba, v. 38, n. 85, p. 107-114, 2010.

SIMÕES, D.; FENNER, P.T.; ESPERANCINI, M.S.T. Avaliação técnica e econômica da colheita de florestas de eucalipto com harvester. Scientia Forestalis, Piracicaba, v. 38, n. 88, p. 611-618, 2010.

STAMPFER, K.; LOSCHEK, J. Harvester operations increase productivity of cable extraction systems. Österreichische Forstzeitung (Arbeit im Wald), Klosterneuburg, v. 110, n. 2, p. 4-6, 1999.

STORE, R.; KANGAS, J. Integrating spatial multi-criteria evaluation and expert knowledge for GIS-based suitability modeling. Landscape and Urban Planning, London, v. 55, p. 79-93, 2001.

ZAMBON, K. L.; CARNEIRO, A. A. F. M.; SILVA, A. N. R.; NEGRI, J. C. Análise de decisão multicritério na localização de usinas termoelétricas utilizando SIG. Pesquisa Operacional, Rio de Janeiro, v. 25, n. 2, p. 183-199, 2005.

Received: 2018/11/12

Accepted: 2019/03/04 